\title{
China Factor in the Sudan Crisis: A Politico-Economic Perspective
}

\author{
Assad Mehmood Khan ${ }^{1}$, Nazim Rahim*1 \& Musab Yousufi ${ }^{2}$ \\ 1. Department of Political Science \& International Relations, Qurtuba University, Peshawar, Pakistan. \\ 2. Faculty of Social Sciences and Humanities, Riphah International University, Islamabad, Pakistan.
}

Received: June 12, 2020

Published Online: December 30, 2020

\begin{abstract}
China has recognized a more far-reaching factor in Sudan for the last two decades and so, during that it has developed into a blend of lasting ferocious inner volatility and prolonged outward misfortune that has described the political affairs of the central government since 1989. China factor among two inter-linked politico-economic trajectories of Sino-Sudan engagements is studied in this research article. The foremost concerns China's relationships with Sudan's national government in integrating China into its national political affairs and international relations over long established crisis in Darfur region of Sudan, to which China has reacted over a more affianced political character. The other provokes the practical precincts of China's independence principle and limited dependence over dealings with the Sudan's national government. Following the uncertain events since 2003 in Darfur, China has established a new relationship with Sudan, thus pursuing to place herself to circumnavigate Sudan's crisis. This research article effort to review a specific context of China factor in Sudan crisis with more focus over the recent politico-economic engagement with Sudan.
\end{abstract}

Keywords: African Studies, China's Foreign Relations, Sudan's Foreign Policy, PoliticoEconomic Relations, Non-Interference Policy, Foreign Direct Investment.

\section{Introduction}

China is asserting and perceiving its factor and character as politico-economic engagement in Sudan crisis within a fast-evolving international order (Large, 2009). The gasping arid province of Darfur remains one of its central arguments where differing securities unify into a difficult as well as a lot perplexing learning progression. Hence, China had to manoeuvre the situation insisting politico-economic benefits in a manner that circumvented clashes with other players and evaded the drawbacks associated to indigenous uncertainty and anxiety (Tunsjo, 2013). Beijing's viable incentives in the North-African states in general and Sudan in particular are broadly surveyed. Conferring to the United Nations, Chinese characterizes as considerably up to 64 percent of Sudan's economic capacity. Sudan's oil trade to China amplified over 6.5 million-tons to pervious 266,126 in 1999-2006. Whereas China oil-trade with Sudan in year 2017 was up to US dollars 405.17 million over 47 percent of Sudan's entire oil explorations (Economics, 2020).

Thus, making it possible for China National Petroleum Corporation (CNPC) single-handedly channelled over US dollars 4 billion within the marketplaces of Sudan (Nour, 2013). Moreover, CNPC remains the leading stock holder as well as a dynamic player in Sudan as 1996. It has 
been the key stockholder of 40 percent in state oil corporation of Sudan in 1997, operating as the Greater Nile Petroleum Company (GNPOC). It learned numerous oil utilization concerns. It reflects approximate domination over the massive oil chunk in Darfur region, thus contributes straight in three newly developed Oil exploration zones, whereas secondarily through GNOPC in two supplementary zone areas. CNPC has a vital character in the expansion of Sudan's oil structures. During 1998, CNPC's production division, along-with China Petroleum Engineering and Construction Corporation (CPECC), contributed in the construction of over 1,500 km channel in the southern region to the Red Sea (Nour, 2013). In 2004, Sudan's central authority presented CNPC an agreement to improve another $740 \mathrm{~km}$ oil channel linking the Fula oil-fields in Western Kordofan region to the central oil processing plant in capital city, Khartoum. Moreover, Chinese corporations are also factoring in numerous other subdivisions of oil exploration fields.

Chinese corporations also grasp over 50 percent of its portion in the Khartoum Chemical Industry Company (KCIC), and is proprietor of the Sudan's petro-chemical business projects. China's Harbin Power Company, with the financial assistance and support of US dollars 149 million credit from China's Central Bank, established as well as accomplishes the Qarre-I hydro-power location, nearby $50 \mathrm{~km}$ north of capital of Sudan. Thus, accompanied by QarreII it has the capacity to yield over 330megawatts (Nour, 2013). Moreover, through an 85 percent of shares, the China also contributed within 300 megawatts project of Kajbar Dam. Furthermore, many other corporations from China are engaged in the building of passages, railway-tracks, and other community-based projects in Sudan. China's trade and industry drives have been challenged by Sudan's depressed politico-security environments. Thus, threating beyond once to China's projects taking place in different regions of Sudan. Numerous oil-wells are situated in bordering regions of crisis zones. In 2004, insurgents seized Chinese labours who were moving to the southern region of the state.

China's politico-economic drives too have been confronted indirectly by the international peace settlers. Though, Beijing devotes amassed determinations to make itself equally answerable player within the global peace settler community. Thus, introducing multi-field, multi-levelled besides multi-channel collaboration contained by the international peace settler community has developed the representative excellent. Li Zhaoxing, the Chinese Foreign Minister endorsed that the dynamic character for peace making process, progression, and collaboration by the public of every state has shaped a flow of account, thus Chinese diplomatic policies have made courageous progression, helping internal progression of the states, and contributed to international peace-making process besides collective improvement. Though, pandemonium over Darfur crisis heaved reservations on these principles. Not merely was China condemned for supportive to the government of Sudan on pledging war law-breakings, but the crisis in Darfur also position edit in a tight spot concerning two deviating features of its innovative ambassadorial principles.

China, on the one-side customary emphasizes overstate sovereignty and non-interference, the principles demonstrated to be productive in carving-out politico-economic factor in Sudan besides anyplace on African continent. Zhou Wenzhong, China's Deputy Foreign Minister, summarized in 2005, that professionalism is professionalism and they are trying to distinct political affairs from commercialism where the inland state of affairs of Sudan are internal matters. While, on the other-side, Li the Chinese minister emphasized on, evidently productive politico-economic engagements which are essential to preserve virtuous relationships with other internationals and to maintain a character in multidimensional officialdoms. Thus, 
China's engagement strategy on Darfur issue proposes a pertinent example to review that how it resolves pursuing diminutive advantages besides the necessity for enduring permanency in Sudan and opportunities of former players. Concerning philanthropic disasters approximating in Darfur, accountability has every so often been quantified to the obligation to safeguard. This liability suggests that a player has the obligations and conditions to put-aside the supremacy of independence when any government is unable to safeguard its populations.

Evidently, the wide-ranging examination has concentrated on China's developing posture over principal in crisis and conflict management zones, particularly in the perspective of the UN missions. Thus, such examinations disclose China's posture over UN Peace-keeping missions that has altered from righteous disagreement besides non-participation in 1970s, then backing and non-participation in 1980s, to back and participate in 1990s. Although, China endorsed a comparatively fixed explanation of independence, then in belief contrasting the impression of interference (Hodzi, 2018). Thus, leadership in China is also dedicated to a succession of multidimensional endeavours that progressively improved China's posture over intermediation then, by postponement, independence's character in global politics.

UN Security Council's function as to safeguard and venture countrywide securities is progressively documented by the government of China. Later 1970s, Chinese also taking place to perceive productive collaboration in the context of the $\mathrm{UN}$, particularly the essential character of co-occurrence by the West as well as the US in specific (Hodzi, 2018). Numerous academics underlined the statistics that politico-economic inter-dependence along with China's growing position in place of a regional as well as emerging global power, wind-swept the importance of independence in transnational dealings. Multi-years of association of the UNSC has too directed to a substantial development of politico-economic learning in that China redefined its principles as well as resources. However, though China concluded to participate in numerous peace-keeping missions by validating through its vote of veto in the UNSC then by dynamically supportive on ground, this commitment was shortly challenged by new representativeness (Herman, 2015).

The consequential transference from peace-keeping to peace-enforcement necessitated Chinese to review its point yet again. Thus, response was a practical effort to evade clash among the need for commitment besides China's precondition of national consensus. Henceforth, China answered to peace-enforcements by remaining indifferent and separating the enactment and understanding to former players. It is precisely confronted with the current crisis in Darfur and instability in Sudan. Assumed the vital factor of China in Sudan crisis and its closed concern over politico-economic engagement with the government, it was enforced into the exposed. Consequently, it is further most convenient to get into further features on in what way it exasperated to response such encounter.

This research attempts to evaluate a particular perspective of China factor in Sudan crisis with further emphasis on the current politico-economic commitments with Sudan. For instance, uncertainty in Sudan by distinctive mention of Darfur skirmish is not simply the motive of China's politico-economic commitment, however its conferred fiscal concerns seized it to the area. Sudan is deepened with reserves predominantly the oil besides gold assets which might justify the difficulties and necessities of various energy wanted countries. This situation essentially shaped a power struggle identical state in Sudan as 2003, as many challenges and existing state of affairs do not allow to offer unrestricted influence of China to cash the landcapital of Sudan. However, core question to address will encompass the politico-economic 
importance of Sudan for outside players like China and how Darfur allowed a space to the external factors with special focus over China's factor in Sudan's politico-economic developments since 2003.

\section{Theoretical Framework}

In this research article, data will be evaluated applying "Realist Theory" so as to understand the states' conduct and relationships. Thus, conclude the prospects of China factor in the Sudan's politico-economic perspective referring Darfur issue. Sino-African engagement in general and Sino-Sudan in particular is considered in terms of quest for energy resources encompassing: control over raw-capital (Westphal, 2017), domination over natural resources (Mearsheimer, 2016), hold over flea-market, and competitive gains over industrial productions. Furthermore, the existing deliberation to value Sino-Sudan associations, expressively relates the realist explanations, therefore symbolizes China's strategic interests as decisive by guarding its economic securities (Oil \& Gold), persuading protection of its energy requirements, largely related to geo-political and geo-strategic struggle in the area (Asongu et al., 2018). Consequently, China factor in politico-economic relationships with Sudan appears as self-regarded empowerment that is rescuing raw-capital for home-industry.

Consequently, to reach, the precise objective of our research, maintaining the theoreticalframework of Realism, focuses over China's soft-power policies particular to Darfur in accord with the main support of 'Political Realism', where the primary goal of countries focuses their state-interest sand "determined in-terms of supremacy" (Morgenthau, 2007). Furthermore, framing soft-power, as concluded by Joseph S. Nye, "Soft-power is not simply as influence but the capability to form the partialities of others" (Nye Jr., 2009). Thus, the further intent focuses on comprehending aforesaid theory remaining in the context of the politico-economic relationships within international order in order to analysis through which features that shaped Sino-African relations in general and Sino-Sudan in particular since 2003, Darfur issue (McGiffert, 2009; Johanson, 2016). Hence, this will enable exploration to endorse and form the realistic factor of Sino-Sudan politico-economic relationships.

\section{Methods and Material}

Primarily, the qualitative method of study used to conclude this research article. Accordingly, a reasoned, illustrative besides descriptive scheme of "qualitative-research" applied while attempting the research. Furthermore, to gauge the politico-economic factor of Sino-Sudan relationships, issues including human-rights, policy of non-interference, military relations, energy-politics, interests of raw-capital, structural developments and FDI are mainly considered in interpretative method. Additionally, the study utilized method of historical research, mainly reviewed existing readings besides historiographic study, to make some validation and attributions.

The research focused on "secondary-sources" of data. Thus, mostly depended on publications by the scholars on the topic, suitable book-readings, applicable research-articles, speeches and principal statements by the state's spokesmen, exclusive reports, citations, particular websources; periodical sand journals on the subjects, and e-papers are chosen and re-viewed establishing the implication on the research. Principally, the tools for data collection included analysis of opinion-based interviews of subject experts. 
Moreover, the observations are constructed around the news-sources, stories and live-reports on selected and reputed e-media including CNN, BBC, African News, Africa Today and Xinhua news network, besides employment experience in African region DR Congo and Darfur region of Sudan in 2009 and 2016-17 separately. Furthermore, exploration of existing readings and papers published by UN, World-Bank, HRW and IMF; pdf as well as e-books, presumed international e-newspapers like NYT, WP; China's People Daily Online and CNTV English; African e-newspaper in English the Financial Gazette etc have been used.

Primarily, the data has been analyzed through "content-analysis" technique[s] by means of enquiry practices like "What" (descriptive) and "What was meant" (interpretative). Moreover, the procedure of "discourse-analysis" remained valuable for the valuation and learning of popular discourses as existing in the academe, media besides the personalities. The dependability on secondary-sources remained limitation of the research besides evaluation of differing views of academia concerning the subjects. While it also primarily focused on the factor of politico-economic dealings in the Sino-Sudan relations within the framework of Darfur issue.

\section{Analysis and Discussion}

Evidently, Sino-Sudan relationships developed since Sudanese inception, once Sudanese were acknowledged through ruling party in China. Therefore, Sudan become the foremost state in sub-Saharan Africa that recognized representative interactions through Chinese later transformation of communists in the state.

\subsection{Sino-Sudan Engagement Recount}

Though, China has a long his of its diplomatic relations with Sudanese as long since 1959, however, it developed dynamically after petroleum-oil exploration in Sudan since early nineties and emerged under politico-economic prospects since 2003 after Darfur issue. Since, 1990s, the evolving relations between two states developed into petrol trade and commodities exchange character, thus merged as China's new factor in Sudan's instability crisis and politico-economic concerns in international order (Shinn, 2009). Moreover, such oil-trade relations attracted large investment, thus Chinese developed an image of foremost importations besides exportations factor among competitors.

Moreover, since 2003, subsequent to Darfur problem, Chinese provided an overt support aimed at its inland drives towards energy requirements (Chen, 2016). However, it revisited its policies towards Darfur issue, particularly since separation of South-Sudan, and too through an active participation in UN mission deployed in Darfur. Thus, redesigned its image in international order, particularly with reference to 'non-interfering' strategy towards conflict mediation. Moreover, since launch of Chinese 'Belt and Road Initiative' (BRI) (Johnston, 2019), China factors in politico-economic stability of Sudan has too been revisited through dominant character of smooth exit of UN from Sudan and transition towards politico-economic stability aimed authority change since 2019 coup (Rahim et al., 2019).

\subsection{China Factor in Sudan Crisis}

China and Sudan ceremoniously celebrated February 4, 2009 as $50^{\text {th }}$ anniversary of their ambassadorial relationships, once China developed the $4^{\text {th }}$ ambassadorial operation in Sudan 
within African continent. The ceremonious celebrations were surpassed after the International Criminal Court (ICC), issued the apprehension permit for then in power president, Omar alBashir on explanations for criminalities in contradiction of human kind besides accounts of war misconducts (Weisbord, 2019). Outside reportage of these momentous proceedings demonstrated and sustained the predominant disparity among Sudan such as a concern in SinoAfrican and global affairs besides China's factor of politico-economic engagements in Sudan. Sino-Sudan relationships have been a conspicuous fragmenting its contemporary worldwide political affairs, further most evidently viewed before the Beijing Olympics in 2008, however China has also established a further reputable, substantial factor in Sudan (Budabin, 2011). Though, it has acknowledged a lesser amount of consideration, spaced out after such events as the assassination of Chinese labour working in oil-fields in Sudan during 2008 by rebellious militaries in Southern-Kordofan province of Sudan, which under scored the coldness among formal storylines of unique two-sided relationships and the larger convolution of China's engrossment in Sudan's politico-economics in general (Deng, 2008).

This paper deliberates how China factor in Sudan's politico-economics has established during the last two-decades and so. For instance, the consequence of a grouping of a further recognized politico-economic character and repetitive crises linking internally as well as externally to Sudan, this reproduces a primary transformation in Sino-Sudan relationships. Throughout the socialist era up until 1990s, Beijing organized a profuse politico-economic mutual relationships pomposity of independence, equivalence, non-interference, and commonality; amid whatever was generally a scanty content of assistance, employment, and governmental relationships in Sudan. Most currently, and particularly as the initiation of oil-capital ventures after the laterquarters of 1990s, the extension of Sino-Sudan politico-economic relationships have preordained that significant diplomatic relations doctrines have been extended in scanty contents method over profuse contents method. The expansion of progressively practical politico-economic interests has necessitated a further politico-economics if I can't character for China within Sudan, consecutively, an influence by Sudan over China's global order. The politico-economic development of the National Islamic Front (NIF) subsequently detained supremacy during 1989, been significant to China's varying engagement factor.

In the midst of crisis and uncertainty in Sudan, the central authority at Khartoum challenged prolonged out ward difficulty and made China in place of its strategic worldwide supporter. Therefore, the relationship that emerged afterwards 1989, appeared to be since relevant of shared government-to-government values generally unfettered by politico-economic impediments established into a further entrenched, strategic besides multi-dimensioned engagements (Large, 2009). Simultaneously, China has also continued with its fundamental principles aiming mutual relationships with Sudanese government; thus, significantly sovereignty-based non-interference, however, verified challenging dynamics. Consequently, Chinese has retorted by developing its politico-economic engagements with Sudan. The main purpose at this point is to discover China factor in Sudan's politico-economic engagements by probing into China's varying engagements with Sudan within the concurrence of prevailing crisis in Darfur region.

\subsection{Sino-Sudan Politico-Economic Engagements: A New Factor}

Current consideration to Sino-Sudan relationships has inclined to opportunity for China's worldwide mediation over conflict in Darfur. Sino-Sudan politico-economic engagements could possibly be viewed by different school of thoughts; hence descriptions can be recognized 
in varying methods for China's factor in Sudan crisis. The realists 'description, the foremost and noticeable, recognizing China's politico-economic character as inspired by security of economic benefits mainly the oil-capital, a factor of energy sanctuary domineering, thoroughly linked to influence policies and geo-strategic struggle with US (Legro \& Moravcsik, 1999). The social constructivists' description, the outward support activated a standardizing development in China concerning a more constructivist commitment in Sudan predominantly with respect to Darfur conflict; its mediation policies transformed from impassive, ambience backing of Sudan's government to more vigorous participation in diplomatic engagements meant at concluding crisis in Darfur (Tadros, 2013).

The classical liberalists' description, the extremely critical interpretations of China factor in Sudan, emphasizing an optimistic character, stressing the remunerations of increasing business and cost-effective development for reconciliation in Sudan crisis (Large, 2009). All interpretations might have rationalization for definite dynamics of Chinese politico-economic engagements and increase imperative concerns, however have largely ignored to such engagements in Sudan. The means by which China factor has influenced politico-economic engagements in Sudan in recent years, is therefore commendable of extra deliberation.

A renewed chapter of Sino-Sudan engagements in recent account of relationships has extended over the last two-decades. Earlier to oil-capital ventures, China's factor in Sudan was, intended to be more representational than politico-economical consequential. China's factor in Sudan today have been repositioned in relation to the politico-economic domains particularly with the development of the National Islamic Front (NIF) government since 1989 (Large, 2010). Thus, followed pre-existent design of government accustomed by the determinative past phases that formed present Sudan. The primary character of politico-economic governance donated by colonization, that would be conspicuously verbalized and experienced by governmental Islamization, a profound dictatorship connected to faith within socio-ethnic authority of central government. Present-day Sudan being administered through hyper-active principal however insecure politically aware epicentre. The foremost provinces of Sudan including Darfur and Kordofan regions have practiced politico-economic marginalization, causative to prevailing crisis. Thus, significantly contain the extended armed struggle resulting insurgence that effected Sudan's normalcy in general and spread in Darfur region particularly since 2003. Hence, resulted into over 400,000 deaths up till 2015 , the internally displaced population of over 2.6 million persons.

During years 2003-04, a predominantly penetrating as well as overwhelming state-supported counter-insurgence drive was carried-out, resulting violence by the insurgents from Sudan Liberation Army (SLA) on a national air-base located at Al-Fasher, major city in Darfur region during April 2003 (Grieco, 2010). Since access to interests; Sudan's policies developed around party-politics however China was engaged for support amid long-drawn-out civil-war, US steered restraint strategy and worldwide consents over Sudan. Thus, a resource capital state like Sudan was viewed as a beneficial, hence, besieged as enduring oil-capital provider and ground to sustenance the worldwide expansion of China's businesses. Therefore, mutual relationships extended in a comparatively low-profiled means, endorsed by situations and the unintentional significances of West than somewhat usual diplomatic attraction. Sudan emerged as ideal spot of commitment for Chinese engagement on African continent preceding the development of its relationship's later 2000. However, the two-sided relationships were outlined in relations of the politico-economic model led by oil-capital ventures. Thus, a resilient difference to the conflict and forced policies of US in specific, appropriate to the regime in 
Khartoum, positioned precise significance over China factor in Sudan with strategy of nostrings or non-interference.

Sino-Sudan politico-economic relationships have established starting with relatively lowprofiled to utmost vital outward economic politico-economic collaboration. Moreover, China's viable growth within Sudan did not acquire space in a void however somewhat gained a politico-economic relationship in that many external factors had been and would be dynamic. Sudan, though, has developed a focused politico-economic relationship of China's interests, continual to increase in current ages. Oil-capital and ventures remain at the top of relationships and governs Sino-Sudan trade and business engagements. Sudan remained sixth-biggest oilcapital provider to China during 2007, thus making six percent of total oil-capital imports of China; moreover, Sudan has remained a strategic player for China among African impartiality oil-capital investments. Whereas, total business grew progressively and reached US dollars 5.7 billion during 2007, besides China's export of manufactured goods to Sudan's market increasing significantly above the last years (Amineh \& Guang, 2010). Oil-capital investments have reinforced the succeeding developments of a further varied display of China's corporate activities. politico-economic relationships, however, un-balanced: in contracted politicoeconomic terms, China factor to Sudan far surpasses Sudan's factor to China.

\subsection{China's Changing Position over Darfur}

China certainly not conflicted the placement of UN peacekeeping mission in Darfur, however it persistently denied a peace implementation procedure, suggesting placement of troops without essentially gaining the assent of the domestic regime (Zhu, 2010). Chinese even had numerous incentives to direct in blue-berets. Primarily, responsiveness raised that mounting ferocity would place its politico-economic interests in Sudan at threat. Numerous experts from China, directed at a possible fall-out of turbulence in Darfur to other regions. Furthermore, depreciations could also activate durable autonomous rejoinders from West that too threat China's politico-economic associates and mark China drop its central place. Secondly, the AU's demand to substitute its drained soldiers with planned UN peace-keeping mission in Darfur could harm its association with further African countries in the situation of impediment. Thirdly, the re-establishment of politico-economic relations with Chad during 2006 and 2007, would be challenging as Chad being a bordering country had been enduringly persistent for role to stopover immigrants besides insurgents floating from Darfur. Thus, considering China's oil-capital interests extending as of Libya toward Ethiopia and all nearby Western regions of Sudan, permanency becomes vital to its energy sanctuary (Taylor, 2006).

However, during August, government at Khartoum straightforwardly overruled any substituting of African Union (AU) combatants with peacekeepers from UN (Kagwanja, 2007). Furthermore, government of Sudan deteriorated an offer to appear at distinctive conference of the UN Security Council then the associated sign to cut-down the magnitude of the premeditated UN manoeuvres in Darfur. Thus, US along with some states from Europe and Africa wanted to upsurge stress. The US exposed new-fangled consents as the extension of UN resolve 1706 to deploy peacekeepers in Darfur region appeared close (Black \& Williams, 2010). China's party-political leadership visibly communicated their apprehensions, with the purpose of together refusing condemnation over China's stance besides displaying before the government of Sudan that it touched upper limits. Such as, during September, Wen Jiabao specified that it was desperately worried about the permanency in Darfur region besides repeated support to approval of peace-keepers in Darfur (Medeiros, 2009). 
Zeng, the Vice-President of China supposedly elucidated that the UN peacekeepers in Darfur region would not challenge the authority of state government in Sudan in addition it was suggested to begin with productive consultations on the conceivable viewpoint of this mission. Wang, the Chinese diplomat long-established that China had been persistent to Sudan by stating that it directed a memorandum referring UN peacekeeping as supported impression, however it is government of Sudan to decide and agree to it (Waldron, 2008). While Sudan to conclude appeared in the summit of the high-level session with particular reference to crisis in Darfur region in the headquarters of the African Union (AU) at Addis Ababa, Wang was recounted for constructing significant intrusions to get the contract of the deployment of peaceforces, a road-map of a hybrid mission of African Union (AU) and UN peacekeepers comprising of 22,000 peace-keepers (Murithi, 2013). In addition to the dispensing four codes of conduct for resolution of the Darfur crisis, besides visibly affirming that the regime to exert more sincerely to contract peace-making in its conflicting-zones, $\mathrm{Hu}$ Jintao along-with attending representatives were observed to have referred a vibrant communication that the UN peace plan to be appreciated (Wuthnow, 2013). Henceforth, China's peacekeeping lifted progressively from transitory the communication to vigorous influence.

Although, government of Sudan maintained its gravity over China by using oil-capital, however, a firm stance was shaped by MFA of China. Furthermore, ruling party besides staterun institutes anxious to the subject, here were rising demands for manoeuvring backing out of Sudan's government then leaving a collective forward-facing towards the West, hence the worldwide communal-authorities to endure applying weight over Sudan. Consequently, a novel chapter of straight pressure by China took place, afterward China developed that the method of appeasement as well as silent mediation was incomplete once engaging with the government at Khartoum. The reaction of the Omar Al-Bashir, then president of Sudan was surprise, as stated that government of Sudan is persuaded that Beijing would not assume, to be tool of American force in contradiction of Sudan (Sriram, 2008).

Furthermore, a statement by Ali al-Sadiq, state spokesman in MFA clearly communicated concern by stating that China is considered strategic partner of Sudan, thus would continue working by organized ambassadorial discourse with Sudan, thus US efforts towards China would be unproductive (Ahmed, 2010). China's new-fangled strategy concerning Darfur issue extended its culmination with the employment of special-envoy by China over African matters in general and Darfur in particular. Moreover, China also declared employing 275 army engineers as UN peacekeepers in Darfur (Black \& Williams, 2010). Furthermore, it too agreed for assignment of few engineers already contributing in peace-keeping operations in SouthSudan diverted towards the Darfur in assistance to newly deployed military engineers to take part in structuring the sites besides the flattening of ways, thus formulating placement of additional UN peace-keepers.

\section{Conclusion}

China, as an important player of world order, is comparatively novel to the experiment of dealing the composite subjects of reconciliation and refuge away. However, the instance of Darfur, representatives from China, shortly developed responsive that its strategy of unconditional sustenance to the government of Sudan besides non-interference within domestic matters would engage with Chinese larger concern of supportive to the West in its character as an answerable shareholder among global communal. Thus, contextualizing further operative methodology of the global communal concerning China would be refrain from reproach 
besides acknowledgment of its continuing change towards novel strategy engagement. China factor in Sudan crisis particularly Darfur issue necessarily established China's politicoeconomic dexterity. It forced China to deviate amid its customary models and politicoeconomic interests on the one-side, while on the other-side the worldwide pressure besides the necessity for extended period of solidity. Moreover, novel expansion would have happened with the globalization of the issue in Darfur, that has consequences over larger sensitivity of China factor in African affairs in general and Sudan crisis in particular. Consequentially, it would necessitate engagements on African continent in directive to develop its appearance along-with the community judgement in the forthcoming.

\section{References}

Ahmed, G. K. (2010). The Chinese Stance on the Darfur Conflict. South African Institute of International Affairs (SAIIA).

Amineh, M. P., \& Guang, Y. (2010). The Globalization of Energy: China and the European Union. BRILL.

Asongu, S., Nwachukwu, J. C., \& Aminkeng, G. A. (2018). Lessons from a Survey of China's Economic Diplomacy. Journal of World Trade, 52(4), 789-814. https://www.econstor.eu/bitstream/10419/191332/1/agdi-wp-18-009.pdf

Black, D. R., \& Williams, P. D. (2010). The International Politics of Mass Atrocities: The Case of Darfur. Routledge.

Budabin, A. C. (2011). Genocide Olympics: How Activists Linked China, Darfur and Beijing 2008. In D. Large, \& L. A. Patey, Sudan Looks East: China, India \& the Politics of Asian Alternatives (pp. 139-156). Boydell \& Brewer.

Chen, Z. (2016). China and the responsibility to protect. Journal of Contemporary China 25(101), 686-700. https://doi.org/10.1080/10670564.2016.1160500

Economics, T. (2020, May 1). Trading Economics. Trading Economics: https://tradingeconomics.com/sudan/exports/china/crude-oil-petroleumbituminous-minerals

Grieco, M. (2010). Failed and Failing States: The Challenges to African Reconstruction. Newcastle upon Tyne. Cambridge Scholars.

Herman, F. (2015). China's African Peacekeeping Decision-making in the Hu Jintao Era. Vij Books.

Hodzi, O. (2018). The End of China's Non-Intervention Policy in Africa. Springer.

Johanson, D. (2016). China's Soft Power in Sudan: Increasing Activity but How Effective? In X. Zhang, H. Wasserman , \& W. Mano , China's Media and Soft Power in Africa (pp. 181-192). Palgrave Macmillan.

Johnston, L. A. (2019). The Belt and Road Initiative: What is in it forChina? Asia and the Pacific Policy Studies, 6, 40-58. https://doi.org/10.1002/app5.265

Kagwanja, M. (2007). Protection of Civilians in African Peace Missions: The Case of the African Union Mission in Sudan, Darfur. Institute for Security Studies.

Large, D. (2009). China's Sudan Engagement: Changing Northern and Southern Political Trajectories in Peace and War. The China Quarterly, 199, 610-626. https://doi.org/10.1017/S0305741009990129

Large, D. (2010). The End of Abstraction: China's Development Relations with Sudan. In C. M. Dent, China and Africa Development Relations (p. 208). Routledge.

McGiffert, C. (2009). Chinese Soft Power and Its Implications for the United States: Competition and Cooperation in the Developing World. CSIS. 
Mearsheimer, J. J. (2016). Structural Realism. In T. Dunne, M. Kurki, \& S. Smith, International Relations Theories: Discipline and Diversity (4 ed., pp. 71-88). Oxford University.

Medeiros, E. S. (2009). China's International Behavior: Activism, Opportunism, and Diversification. Rand Corporation.

Morgenthau, H. J. (2007). Politics Among Nations: The Struggle for Power and Peace. Knopf. Murithi, T. (2013). Handbook of Africa's International Relations. Routledge.

Nour, S. M. (2013). Technological Change and Skill Development in Sudan. Springer Science $\&$ Business Media.

Nye Jr., J. S. (2009). Soft Power: The Means To Success In World Politics. PublicAffairs.

Rahim, N., Khan, A. M., \& Bukhari, S. M. (2019). Political Instability in Sudan after Military Coup: Implications for China's Economic Interests. Liberal Arts \& Social Sciences International Journal (LASSIJ), 3(2), 1-10. https://www.ideapublishers.org/index.php/lassij/article/view/20/19

Shinn, D. H. (2009). China and the Conflict in Darfur. The Brown Journal of World Affairs, 16(1), 85-100. http://bjwa.brown.edu/16-1/china-and-the-conflict-in-darfur/

Sriram, C. L. (2008). Peace as Governance: Power-Sharing, Armed Groups and Contemporary Peace Negotiations. Springer.

Taylor, I. (2006). China's Oil Diplomacy in Africa. International Affairs (Royal Institute of International Affairs 1944), 82(5), 937-959. https://doi.org/10.1111/j.14682346.2006.00579.x

Tunsjo, O. (2013). Security and Profit in China's Energy Policy: Hedging Against Risk. Columbia University.

Waldron, A. (2008). China in Africa. Jamestown Foundation.

Weisbord, N. (2019). The Crime of Aggression: The Quest for Justice in an Age of Drones, Cyberattacks, Insurgents, and Autocrats. Princeton University.

Westphal, K. (2017). Grounds of Pragmatic Realism: Hegel's Internal Critique and Reconstruction of Kant's Critical Philosophy. BRILL.

Wuthnow, J. (2013). Chinese Diplomacy and the UN Security Council: Beyond the Veto. Routledge.

Zhu, Z. (2010). China's New Diplomacy: Rationale, Strategies and Significance. Ashgate. 